\title{
The effect of different cold period during maternal incubation on incubation efficiency and hatching term in Austropotamobius pallipes
}

\author{
T. Policar ${ }^{(1)}$, J. Smyth ${ }^{(2)}$, M. Flanigan(3), P. Kozak ${ }^{(1)}$, A. Kouba ${ }^{(1)}$ \\ Received September 29, 2009 / Reçu le 29 septembre 2009 \\ Revised November 23, 2009 / Révisé le 23 novembre 2009 \\ Accepted November 24, 2009 / Accepté le 24 novembre 2009
}

Key-words: white-clawed crayfish, egg, temperature, hatching, survival rate

\section{ABSTRACT}

This study tested the effect on the incubation efficiency ( $E$ in \%) and hatching term during maternal incubation of Austropotamobius pallipes of five different cold periods (duration: 45, 60, 75, 90 and 105 days) under controlled conditions and one group maintained under ambient Irish water temperatures. The six different durations of cold period, used in this study, caused six different terms of hatching from 16 March to 29 June. When compared to the group held under ambient Irish conditions with fluctuating water temperatures during the incubation period ( $E=29.9 \pm 4.5 \%$ ), higher incubation efficiency was found in all groups under the controlled conditions $(E=73.1 \pm 4.7 \%-41.3 \pm 2.7 \%)$. In groups under controlled conditions, a positive effect of shortened cold period on incubation efficiency was found, with the highest efficiency $(E=73.1 \pm 4.7 \%-68.8 \pm 5.2 \%)$ found after the shortest cold period, while the longest cold period led to the lowest efficiency $(E=41.3 \pm 2.7 \%)$.

\section{RÉSUMÉ}

L'effet de différentes périodes froides pendant l'incubation maternelle sur l'efficacité de l'incubation et la date d'éclosion chez Austropotamobius pallipes

Mots-clés : écrevisse à pattes blanches, œufs, température, éclosion, taux de survie
Cette étude a testé l'effet, sur l'efficacité d'incubation ( $E$ en \%) et la date d'éclosion pendant l'incubation maternelle chez Austropotamobius pallipes, de cinq périodes de froid différentes (durées : 45, 60, 75, 90 et 105 jours) en conditions contrôlées comparées à un groupe maintenu à température ambiante des eaux irlandaises. Les six différentes périodes froides, utilisées dans cette étude, conduisent à six dates d'éclosion du 16 mars au 29 juin. Quand on compare au groupe maintenu sous conditions ambiantes irlandaises comportant des variations de température pendant l'incubation ( $E=29,9 \pm 4,5 \%)$, une meilleure efficacité d'incubation a été trouvée pour tous les groupes en conditions contrôlées $(E=73,1 \pm 4,7 \%-41,3 \pm 2,7 \%)$. Dans les groupes en conditions contrôlées, un effet positif des courtes périodes froides sur l'efficacité d'incubation a été trouvé, avec la plus forte efficacité $(E=73,1 \pm 4,7 \%-68,8 \pm 5,2)$ trouvée après la période froide la plus courte, alors que l'efficacité est la plus faible $(E=41,3 \pm 2,7 \%)$ pour la période froide la plus longue.

(1) University of South Bohemia in Ceské Budejovice, Faculty of Fisheries and Protection of Waters, Research Institute of Fish Culture and Hydrobiology, Zatisi 728/II., 38925 Vodnany, Czech Republic, policar@vurh.jcu.cz

(2) Moneycarragh Fish Farm, 60 Dromara Rd, Dundrum, Newcastle, County Down, BT33 ONS, Northern Ireland

(3) Cross-Border Aquaculture Initiative EEIG, 14-15 Grays Lane, Park St. Dundalk, Co. Louth, Republic of Ireland 


\section{INTRODUCTION}

The white clawed crayfish, Austropotamobius pallipes (Lereboullet) is an endangered species in Western Europe (Reynolds et al., 2002) and this species is also regarded as an heritage species (Füreder and Reynolds, 2003). Methods such as captive breeding and ranching using local stocks of $A$. pallipes can be useful during conservation and reintroduction of this species (Reynolds et al., 2002). Ireland, the only country in Europe with $A$. pallipes free from non-native crayfish (Demers et al., 2005), can be considered as a safe place for production of $A$. pallipes for future European restocking programs (Policar et al., 2008). The Irish strain of $A$. pallipes is genetically close to those in Great Britain and Western France and this stock could be used mainly in this area (Reynolds et al., 2002).

Captive breeding of $A$. pallipes for stock restoration including mating and egg laying (Reynolds et al., 1992; Carral et al., 1994, 2000), maternal (Carral et al., 2000; Celada et al., 2001) and artificial egg incubation (Perez et al., 1998a, 1998b, 1999; Carral et al., 2003, 2004), embryonic development study (Celada et al., 1991) and juvenile culture under controlled conditions (Saez-Royuela et al., 2001; Policar et al., to appear), was first established in Ireland during 2007-2008 (Policar et al., 2008).

Water temperature affects incubation duration and efficiency during artificial and maternal egg incubation (Cukerzis et al., 1978; Perez et al., 1998a; Celada et al., 2001). Very high incubation efficiency was recorded under both constant water temperature and under different durations of cold period during artificial egg incubation in A. pallipes (Perez et al., 1998a). However, very low incubation efficiency was found after maternal egg incubation of $A$. pallipes under controlled and ambient temperatures (Celada et al., 2001). That preliminary study of maternal egg incubation in $A$. pallipes under different thermal conditions showed a problem with egg losses compared to artificial incubation (Perez et al., 1998a; Celada et al., 2001). Optimization of the controlled thermal regime during maternal egg incubation is very important for increasing incubation efficiency (Policar et al., 2004).

The aim of this study was to determine the effect of different durations of cold period during maternal egg incubation in $A$. pallipes on the incubation efficiency and hatching term.

\section{MATERIAL AND METHODS}

\section{> CRAYFISH BROODSTOCK}

In total, 240 mature females (mean $\pm \mathrm{SD}$; total length $(\mathrm{TL})=81.9 \pm 6.04 \mathrm{~mm}$; carapace length $(\mathrm{CL})=37.8 \pm 3.23 \mathrm{~mm}$; body weight $(\mathrm{W})=16.6 \pm 3.99 \mathrm{~g}$ ) and 78 males (mean $\pm \mathrm{SD}$; total length $(T L)=86.5 \pm 8.76 \mathrm{~mm}$; carapace length $(\mathrm{CL})=41.9 \pm 4.42 \mathrm{~mm}$; body weight $(\mathrm{W})=$ $27.3 \pm 9.29 \mathrm{~g}$ ) of $A$. pallipes were used for this study. All crayfish broodstock were wild and caught by baited traps in Brookeborough Lake near Brookeborough village (Northern Ireland) and transported to Moneycarragh crayfish hatchery in Dundrum, Northern Ireland.

\section{> EXPERIMENTAL CONDITIONS}

Six groups of broodstock (each of 40 females and 13 males) were created and stocked in six square tanks $\left(100 \times 100 \times 50 \mathrm{~cm} ; 1 \mathrm{~m}^{2}\right.$ surface area) in the Moneycarragh crayfish hatchery to be held under six different cold periods during maternal incubation. The broodstock mated under optimal conditions as described by Carral et al. (1994). After mating and egg laying finished (November 8), all males were removed from each tank according to Carral et al. (2000). At this moment, stripping of eggs in phase I of embryonic development (Celada et al., 1987) and assessments of initial pleopodal fecundity were carried out on 10 berried females from each group. The initial pleopodal fecundity such as the average number of eggs on the female pleopods of each group was determined from these females. The remaining thirty 


\section{Table I}

Duration of each period and total duration of egg incubation (in days) and average water temperature $\left({ }^{\circ} \mathrm{C}\right.$ ) in all used groups during egg maternal incubation in Austropotamobius pallipes.

Tableau I

Durée de chaque période et durée totale d'incubation des œufs (en jours) et température moyenne $\left({ }^{\circ} \mathrm{C}\right.$ ) pour chaque groupe pendant l'incubation maternelle des œufs chez Austropotamobius pallipes.

\begin{tabular}{|c|c|c|c|c|c|c|}
\hline \multirow[t]{2}{*}{ Group } & \multicolumn{4}{|c|}{ Periods (days) } & \multirow{2}{*}{$\begin{array}{c}\text { Total } \\
\text { duration (days) }\end{array}$} & \multirow{2}{*}{$\begin{array}{c}\text { Average } \\
\text { temperature }\left({ }^{\circ} \mathrm{C}\right)\end{array}$} \\
\hline & Initial & Cold & Medium & Warm & & \\
\hline 1 & 5 & 45 & 50 & $30 \pm 3$ & $130 \pm 3$ & $9.3 \pm 4.9$ \\
\hline 2 & 5 & 60 & 50 & $30 \pm 4$ & $145 \pm 4$ & $9.0 \pm 5.0$ \\
\hline 3 & 5 & 75 & 50 & $30 \pm 3$ & $160 \pm 3$ & $8.5 \pm 4.9$ \\
\hline 4 & 5 & 90 & 50 & $30 \pm 2$ & $175 \pm 2$ & $8.3 \pm 5.0$ \\
\hline 5 & 5 & 105 & 50 & $30 \pm 3$ & $190 \pm 3$ & $8.2 \pm 4.9$ \\
\hline 6 & \multicolumn{4}{|c|}{ Ambient fluctuated water temperature $\left(3.5-14.0^{\circ} \mathrm{C}\right)$} & $226 \pm 5$ & $7.6 \pm 2.3$ \\
\hline
\end{tabular}

berried females were kept in the same six tanks at a density of 30 crayfish per $\mathrm{m}^{2}$, with a natural light regime and 1.5 shelters per female.

In five tanks (controlled temperature groups), recirculated water was used. Temperature in these groups was decreased after egg laying from $8.0 \pm 0.3^{\circ} \mathrm{C}$ to $4.5 \pm 0.3^{\circ} \mathrm{C}$ over five days (initial period). Controlled temperature of these groups included initial $\left(6.1 \pm 1.3^{\circ} \mathrm{C}\right)$, cold $(4.5 \pm$ $\left.0.3^{\circ} \mathrm{C}\right)$, medium $\left(9.0 \pm 0.5^{\circ} \mathrm{C}\right)$ and warm $\left(18.0 \pm 0.5^{\circ} \mathrm{C}\right)$ periods during the incubation. The initial period of incubation was reduced (Celada et al., 1988) and the cold period was used early for a modulation of berried females during the incubation when eggs were in embryonic phase II. During the incubation, groups with controlled water conditions, were subjected to different durations of cold period, from 45 days (group 1) to 105 days (group 5). During spawning and maternal incubation, the sixth group was kept within a flow-through water system under the ambient and fluctuating temperatures of Northern Ireland $\left(54^{\circ} 15^{\prime} \mathrm{N}, 5^{\circ} 52^{\prime} \mathrm{W}\right)$. Detailed information about the duration of each period in all groups is summarized in Table I.

Water temperature and quality were measured in each group during the whole study as follows: water temperature at four-hour intervals (i.e. at 12 am; 4 am; 8 am; 12 pm; 4 pm and $8 \mathrm{pm}$ ) with an auto-recording thermometer (model RT-F5x, QiAnatytical Ltd., Czech Republic), oxygen content and \% oxygen saturation daily at 7 am with a oxymeter Pinpoint II (American Marine Inc., USA), pH once per week with a WTW MultiLine P4 probe (WTW GmbH, Germany), and total ammonia and nitrite weekly with a Tetratest AnalySet (Tetra Company, Germany).

\section{> TERM OF HATCHING AND EGG INCUBATION EFFICIENCY}

Approximately ten days before hatching, when eggs were in phase XIII of embryonic development, each berried female was moved to a small plastic aquarium $(200 \times 300 \times 150 \mathrm{~mm}$, volume $9 \mathrm{~L}$ ) with a screen on the bottom. Berried females were held separately in these aquaria until hatching and release of juveniles in stage II, when the juveniles passed through the screen on the bottom of the aquaria. Time of hatching was recorded and CTU (Celsius Temperature Units $=$ degrees Celsius $\times$ days) needed for hatching was calculated for each female in all groups.

After release of juveniles in stage II, egg incubation efficiency (E in \%) was calculated for each female in all groups by the following formula:

$E=(N J / I F) \times 100$, where $N J$ is number of single juveniles in stage II and IF is average initial fecundity found in each group (average number of eggs in phase I of embryonic development calculated from ten females of each group). 
Table II

Hatching term, CTU and incubation efficiency after maternal incubation in Austropotamobius pallipes.

Tableau II

Date d'éclosion, CTU et efficacité de l'incubation après incubation maternelle chez Austropotamobius pallipes.

\begin{tabular}{lccccc}
\hline Group & $\begin{array}{c}\text { Date } \\
\text { of hatching }\end{array}$ & $\begin{array}{c}\text { CTU } \\
(\mathrm{d})\end{array}$ & $\begin{array}{c}\text { Date } \\
\text { of stage II }\end{array}$ & $\begin{array}{c}\text { Initial } \\
\text { fecundity (eggs) }\end{array}$ & $\begin{array}{c}\text { Incubation } \\
\text { efficiency (\%) }\end{array}$ \\
\hline $\mathbf{1}$ & March 16 & $1209 \pm 28$ & March 25 & $81.9 \pm 18.2^{\mathrm{a}}$ & $68.8 \pm 5.2^{\mathrm{a}}$ \\
\hline $\mathbf{2}$ & March 31 & $1305 \pm 36$ & April 9 & $80.6 \pm 20.1^{\mathrm{a}}$ & $73.1 \pm 4.7^{\mathrm{a}}$ \\
\hline $\mathbf{3}$ & April 14 & $1354 \pm 26$ & April 22 & $82.5 \pm 15.6^{\mathrm{a}}$ & $60.5 \pm 3.8^{\mathrm{b}}$ \\
\hline $\mathbf{4}$ & May 2 & $1452 \pm 17$ & May 10 & $81.7 \pm 14.2^{\mathrm{a}}$ & $59.1 \pm 4.2^{\mathrm{b}}$ \\
\hline $\mathbf{5}$ & May 18 & $1561 \pm 16$ & May 26 & $82.3 \pm 15.7^{\mathrm{a}}$ & $31.2 \pm 2.7^{\mathrm{c}}$ \\
\hline $\mathbf{6}$ & June 13 & $1716 \pm 40$ & June 29 & $80.5 \pm 17.5^{\mathrm{a}}$ & $29.9 \pm 4.5^{\mathrm{d}}$ \\
\hline
\end{tabular}

Within a column, values without a letter in common are significantly different $(P<0.05)$ among groups. Dans une même colonne, les valeurs sans lettre en commun sont significativement différentes $(P<0,05)$ entre groupes.

\section{> STATISTICAL ANALYSIS}

All data are presented as means \pm SD. Statistical analysis of data was conducted using statistical software "Statistica 6.1" (StatSoft, Inc., Czech Republic). The non-parametric Kruskal-Wallis's test was used to test for differences in initial pleopodal fecundity and egg incubation efficiency in females from all groups.

\section{RESULTS}

During mating, egg laying and egg incubation, mean $( \pm \mathrm{SD})$ water quality data were as follows: dissolved oxygen $=8.7 \pm 0.2 \mathrm{mg} \mathrm{O}{ }_{2} \cdot \mathrm{L}^{-1}$; oxygen saturation $=82.7 \pm 2.3 \% ; \mathrm{pH}=7.0 \pm 0.1$; $\mathrm{NH}_{3}<0.03 \mathrm{mg} \cdot \mathrm{L}^{-1} ; \mathrm{NO}_{2}^{-}<0.02 \mathrm{mg} \cdot \mathrm{L}^{-1}$. No statistical differences in water quality were observed among all groups.

\section{>REPRODUCTIVE CHARACTERISTIC OF BROODSTOCK}

Mating took place from October 17 to October 28. High percentages of mating (85\%) were observed within four days (Oct. 19-Oct. 22). Egg laying started on October 19 and ended on November 7 , when $100 \%$ berried females were found in all tanks. Statistically similar parameters of initial pleopodal fecundity were recorded in all female groups at the beginning of the incubation. Relatively high numbers of eggs were found on the pleopods in females of all groups, with minimum of $80.5 \pm 17.5$ eggs (group 6) and maximum of $82.5 \pm 15.6$ eggs (group 3). Initial average fecundity such as average numbers of eggs in females from all groups are summarized in Table II.

\section{> TERM OF HATCHING AND INCUBATION EFFICIENCY}

Six terms of hatching resulted from the six different cold periods were applied during maternal incubation. The first hatching was recorded on March 16 (group 1) and the last on June 13 (group 6), 96 days later. Different cold periods allowed hatching to be extended in time, giving different batches of juveniles in stage II (Table II).

The egg incubations in our study lasted between 130 (group 1) and 226 days (group 6) with CTU from $1209 \pm 28^{\circ} \mathrm{d}$ to $1716 \pm 40^{\circ} \mathrm{d}$ depending on which cold period was used (Tables I and II). 
The highest incubation efficiency $(73.1 \pm 4.7 \%-68.8 \pm 5.2 \%)$ was found in two female groups (groups 1 and 2) under controlled conditions with the shortest cold period of the incubation. Lower incubation efficiencies $(60.5 \pm 3.8 \%, 59.1 \pm 4.2 \%$ and $41.3 \pm 2.7 \%)$ were recorded in groups 3, 4 and 5, where longer cold periods of the incubation were applied under controlled conditions. The lowest incubation efficiency $(29.9 \pm 4.5 \%)$ was evident in group 6 (without any cold period) which was kept under ambient fluctuating water temperatures (Table II).

\section{DISCUSSION}

Environmental conditions (e.g. temperature and light regime), occurance and processes of mating and egg laying in the broodstock of this experiment were comparable to those of other studies into reproduction of $A$. pallipes in Ireland by Woodlock and Reynolds (1988) and Reynolds et al. (1992). However, rather than the sex ratio (1 male:2 females) used in A. pallipes by Carral et al. (1994), a larger sex ratio (1:3) as used with Astacus astacus was applied following Policar et al. (2004). This sex ratio produced good results with $100 \%$ mated and berried females recorded at the end of the spawning period. High efficiency of spawning was achieved in this study because mature broodstock with good sex characteristics were used (Carral et al., 1994). A higher density of broodstock $\left(53\right.$ crayfish $\left.\cdot \mathrm{m}^{-2}\right)$ compared to densities such as $21-24$ crayfish per $\mathrm{m}^{-2}$ and 15 crayfish per $\mathrm{m}^{-2}$ as used by Carral et al. $(1994 ; 2000)$ was used during the spawning period without negative impacts on the percentage of mated and spawned females.

The average pleopodal fecundity of between 80.5 and 82.5 eggs was relatively high and well balanced in all female groups compared to the findings of Carral et al. (1994) and Brewis and Bowler (1985). Larger females $(C L=37.8 \pm 3.23 \mathrm{~mm}$ ) were used in this study, therefore a higher number of pleopodal eggs were recorded. Pleopodal fecundity data versus female size corresponded with the results of Brewis and Blower (1985), Rhodes and Holdich (1982) and Carral et al. (1994).

During maternal incubation, egg losses i.e. incubation efficiency are influenced by the conditions of the incubation including the main factors such as: density of broodstock (Taugbøl and Skurdal, 1990), presence of males during maternal egg incubation (Carral et al., 2000) and water temperature regimes (Cukerzis et al., 1978; Celada et al., 2001; Policar et al., 2004). Mixed males and females and low densities of broodstock have been used during maternal egg incubation under outdoor conditions (Carral et al., 2000). Intensively controlled broodstock management has used higher densities (Taugbøl and Skurdal, 1990; Carral et al., 2000; Policar et al., 2004) and separation of berried females (Carral et al., 2000). Maternal egg incubation of astacid crayfish under controlled conditions can be a very effective means of crayfish production (Cukerzis et al., 1978; Carral et al., 2000; Policar et al., 2004). However, thermal conditions during this maternal incubation must be optimized for good egg survival (Cukerzis et al., 1978; Celada et al., 2001). A cold period during the beginning of maternal incubation appears to be very important in successful egg incubation (Cukerzis et al., 1978; Policar et al., 2004). Lower temperatures during the beginning of maternal egg incubation (i.e. earlier cold period) decreases activity of berried females and egg losses of freshly developing eggs, that are mainly caused at higher temperatures by aggressive behavior among females (Cukerzis et al., 1978; Celada et al., 1988). This result was confirmed by our study, when all cold periods under controlled conditions had positive effects on the incubation efficiency compared to that of the group kept under ambient temperature. During maternal incubation in $A$. pallipes, low egg survival rates $(21.9 \pm 3.8 \%-32.9 \pm 7.7 \%)$ were found by Celada et al. (2001), when constant, ambient and no initial cold period were used. According to these results, we can note that a cold period during early maternal egg incubation has a more significant effect on egg survival than a cold period during the beginning of artificial incubation.

Perez et al. (1998a) found no major effect of low temperature on incubation efficiency during artificial incubation. These authors confirmed good incubation efficiency $(85.0 \pm 0.0 \%)$ in artificial egg incubation under constant temperatures at $8-10{ }^{\circ} \mathrm{C}$. Our results and results 
from study by Celada et al. (2001) confirmed that this water temperature is not accepable for the effective maternal egg incubation. Higher incubation efficiency of artificial compared to maternal incubation was described by Perez et al. (1999) under controlled and constant conditions.

Positive effects of shortened cold periods during maternal incubation of $A$. pallipes on the incubation efficiency and duration of incubation were recorded during this study. A positive effect of shortened cold periods on the shortening of embryonic development during maternal incubation in A. pallipes was published by Celada et al. (2001). However, a positive effect of shortened cold period on incubation efficiency during maternal incubation in $A$. pallipes was not so far found.

Application of different cold periods during the incubation yielded different hatching terms and batches of juveniles for ongrowing as in Perez et al. (1998a) and Celada et al. (2001). This benefit of different thermal regime during the incubation can help breeders better utilize hatchery capacity or equipment and can provide year-round production of crayfish in the future (Celada et al., 1988; Perez et al., 1998a).

\section{ACKNOWLEDGEMENTS}

The authors of this paper gratefully thank Dr. Julian Reynolds (Republic of Ireland) for English corrections. This investigation was financially supported by projects MSM 6007665809, Kontakt ME 855, Interreg IIIA EU and NAZV QH71305.

\section{REFERENCES}

Brewis J.M. and Bowler K., 1985. A study of reproductive females of the freshwater crayfish Austropotamobius pallipes. Hydrobiologia, 121, 145-149.

Carral J.M., Celada J.D., Gonzalez J., Sáez-Royuela M. and Gaudioso V.R., 1994. Mating and spawning of freshwater crayfish, Austropotamobius pallipes Lereboullet, under laboratory conditions. Aquac. Res., 25, 721-727.

Carral J.M., Celada J.D., Munoz C., Saez-Royuela M. and Perez J.R., 2000. Effect of the presence or absence of males throughout spawning and maternal incubation on the reproductive efficiency of astacid crayfish (Austropotamobius pallipes) under controlled conditions. Invertebr. Reprod. Dev., $38,1-5$.

Carral J.M., Sáez-Royuela M., Celada J.D., Pérez J.R., Melendre P.M. and Aguilera A., 2003. Advantages of artificial reproduction techniques for white-clawed crayfish (Austropotamobius pallipes Lereboullet). Bull. Fr. Pêche Piscic., 370-371, 181-184.

Carral J.M., Pérez J.R., Celada J.D., Sáez-Royuela M., Melendre P.M. and Aguilera A., 2004. Effects of dead egg removal frequency on stage 2 juvenile production in artificial incubation of Austropotamobius pallipes Lereboullet. Bull. Fr. Pêche Piscic., 372-373, 425-430.

Celada J.D., de Paz P., Gaudioso V.R. and Fernandez R., 1987. Embryonic development of the freshwater crayfish (Pacifastacus leniusculus Dana): A scanning electron microscopic study. Anat. Rec., 219, 304-310.

Celada J.D., Carral J.M., Gaudioso V.R., Consuelo T. and Fernandez R., 1988. Effects of thermic manipulation throughout egg development on the reproductive efficiency of the freshwater crayfish Pacifastacus leniusculus Dana. Aquaculture, 72, 341-348.

Celada J.D., Carral J.M. and Gonzalez J., 1991. A study on the identification and chronology of the embryonic stages of freshwater crayfish Austropotamobius pallipes (Lereboullet, 1858). Crustaceana, $61,225-232$.

Celada J.D., Carral J.M., Saez-Royuela M., Munoz C. and Perez J.R., 2001. Effects of different thermal treatments on the maternal incubation efficiency of the astacid crayfish Austropotamobius pallipes (Lereboullet, 1858) under controlled conditions. Crustaceana, 74, 801-808.

Cukerzis J.M., Sheshtokas A.L. and Terentyev A.L., 1978. Method for accelerated artificial breeding of crayfish juveniles. Freshw. Crayfish, 4, 452-458. 
Demers A., Lucey J., McGarrigle M.L. and Reynolds J.D., 2005. The distribution of the white-clawed crayfish, Austropotamobius pallipes, in Ireland. Biol. Environ. Proc. Roy. Ir. Acad., 105B, 65-69.

Füreder L. and Reynolds J.D., 2003. Is Austropotamobius pallipes a good bioindicator? Bull. Fr. Pêche Piscic., 370-371, 157-163.

Perez J.R., Carral J.M., Celada J.D., Saez-Royuela M. and Romero M.P., 1998a. Effects of different thermal treatments throughout the embryonic development on the artificial incubation efficiency of crayfish (Austropotamobius pallipes Lereboullet) eggs. Control of the embryogenetic duration and implications for commercial production. Invertebr. Reprod. Dev., 34, 253-258.

Perez J.R., Carral J.M., Celada J.D., Munoz C., Saez-Royuela M. and Antolin J.I., 1998b. Effects of stripping time on the success of the artificial incubation of white-clawed crayfish, Austropotamobius pallipes (Lereboullet), eggs. Aquac. Res., 29, 389-395.

Perez J.R., Carral J.M., Celada J.D., Munoz C., Saez-Royuela M. and Antolin J.I., 1999. The possibilities for artificial incubation of white-clawed crayfish (Austropotamobius pallipes Lereboullet) eggs: comparison between maternal and artificial incubation. Aquaculture, 170, 29-35.

Policar T., Simon V. and Kozák P., 2004. Egg incubation in the noble crayfish (Astacus astacus L.): The effect of controlled laboratory and outdoor ambient condition on hatching success, growth and survival rate of juveniles. Bull. Fr. Pêche Piscic., 372-373, 411-423.

Policar T., Flanigan M. and Smyth J.P., 2008. Intensive production of white-clawed crayfish (Austropotamobius pallipes) for restocking purposes in Ireland. Crayfish News, 30, 8-9.

Policar T., Smyth J., Flanigan M., Kozák P. and Kouba A., to appear. Optimum water temperature for intensive production of Austropotamobius pallipes (Lereboullet) juveniles. Freshw. Crayfish.

Reynolds J.D., Celada D.J., Carral J.M. and Matthews M.A., 1992. Reproduction of astacid crayfish in captivity - current developments and implications for culture, with special reference to Ireland and Spain. Invertebr. Reprod. Dev., 22, 253-266.

Reynolds J.D., Demers A. and Marnell F., 2002. Managing an abundant crayfish resource for conservation - A. pallipes in Ireland. Bull. Fr. Pêche Piscic., 367, 823-832.

Rhodes C.P. and Holdich D.M., 1982. Fecundity of Austropotamobius pallipes Lereboullet in the British Isles. Hydrobiologia, 89, 231-236.

Saez-Royuela M., Carral J.M., Celada J.D. and Perez J.R., 2001. Effects of shelter type and food supply frequency on survival and growth of stage-2 juvenile white-clawed crayfish (Austropotamobius pallipes Lereboullet) under laboratory conditions. Aquac. Int., 9, 489-497.

Taugbøl T. and Skurdal J., 1990. Effect of density on brood size in noble crayfish, Astacus astacus L., subjected to indoor rearing conditions. Aquacult. Fish. Manage., 21, 17-23.

Woodlock B. and Reynolds J.D., 1988. Reproduction in an Irish lake population of the crayfish Austropotamobius pallipes (Lereboullet). Freshw. Biol., 19, 79-86. 